\section{Civil szervezetek az Ormánságban - innováció, integráció, indikáció}

$\mathrm{D}^{\circ}$ lgozatom célja, hogy bemutassam a Szociológia Tanszék 2008/2009-es tanévének tavaszi szemeszterében, az Ormánság meghatározó civil szervezeteit érintô kutatómunkát. A levont konzekvenciák, eredmények ismertetése mellett a felszínre kerülỏ nehézségek lehetséges megoldásait keresem. A civil szervezetek társadalmi integrációra gyakorolt hatásának kérdése, illetve a demokratizálódás folyamatának elõsegitése képezik hipotézisem alapját. $\mathrm{Az}$ in formációgyũjtésben a helyi és könyvtári adatgyũjtés mellett a szervezetek vezetőivel, alkalmazottjaival és a helyi közösség néhány prominens tagjával készített interjúk segitettek. Mindezek elốtt azonban röviden ismertetném a civil szektor néhány, a dolgozat szempontjából lényeges ismérvét.

\section{A civil eszme}

A civil társadalom vizsgálatakor több kérdés is felmerül. Mennyiben tekinthetőek ezek a szervezetek a közélet motorjainak, valamint mennyire segítik a demokrácia kialakulását, fejlődését? A civil szervezetek feladatai és céljai közé elsősorban a hatalom és a társadalom/egyén közötti közvetítés, párbeszéd, a demokratikus folyamatok indikálása, illetve a társadalmi integráció elổmozdítása tartozik. E szervezetek gyakorlatilag a hétköznapi élet minden területén jelen vannak. Megfeleló teret kínálnak a modem demokráciák egyik legfontosabb elvének, az önrendelkezésnek az érvényre juttatása számára. Az önrendelkezési jog, mint alapvetô szabadságjog lehetôséget biztosít a szũkebb és tágabb közösségeknek, hogy létrehozzák saját fórumaikat, érdekvédô szervezeteiket. Ehhez a demokratikusan és jól múködő jogállam megfelelő tetet és keretet kínál. A civil szervezetek a mai kor demokratikus társadalmainak egyfajta „új utat” kínálnak. $\mathrm{Az}$ állami és a piaci szektor mellett egy harmadik szféra lehetőségét nyújtják, ahol az érdekérvényesítés és a társadalmi szükséglet kielégités érvényre juthat. A civil kezdeményezések lehetõséget biztosítanak a közösségek önszervezỏdésére, amiből egyenesen következhet az egyének közötti szolidaritás eszméjének erōsödése is.

Az Európai Unió Gazdasági és Szociális Bizottsága meghatározta a modem civil társadalom föbb ismérveit, melyet az Official Journal of the European Communities címũ folyóiratban közöltek 1999-ben. A civil társadalmat többékevésbé intézményesült szervezetek hálózata alkotja, amelyek autonóm társa- dalmi szféraként müködve nem tartoznak sem az államhoz, sem a családhoz. E szervezetek számos társadalmi feladatot, funkciót látnak el (nemcsak gazdasági, hanem vallási, kulturális, szociális stb. értelemben is), és meghatározó a szerepük a társadalmi integrációban. A civil társadalom intézményes kereteit, az egyének demokratikus alapjogait, a szabad véleményalkotást, valamint az egyesülés szabadságát a jogrendszer biztosítja. Habár a civil társadalom független az államtól, ez természetesen nem azt jelenti, hogy független a törvényektôl is.

A 80-as évek második felétől egyre erősebb társadalmi igény jelentkezett Magyarországon a közösségi élet átalakítására, ebben fontos szerepet játszottak a formálódó civil szerveződések. Ekkor alapították az első településfejlesztéssel, oktatással, egészségüggyel, jogvédelemmel foglalkozó egyesületeket, alapítványokat. A civil szervezeteket legtöbb esetben egy létezô probléma kapcsán hívják életre. Funkciójuk elsósorban olyan szolgáltatások biztosítása, amelyek meghaladják az állam és az önkormányzat teljesítôképességét, illetve kiegészítik azt. Ez különösen igaz a fokozottan hátrányos helyzetben lévő települések, közösségek életében. Ebből kifolyólag került az Ormánság legtöbb települését lefedő Sellyei Kistérség kutatásunk fókuszába, amely az ország 33 leghátrányosabb helyzetủ kistérsége közül a harmadik helyen áll, és a baranyai kistérségek közül az utolsó helyet foglalja el.

\section{A vizsgált területről}

A kutatás témájául a Sellyei Kistérség öt elỗzetes adatgyưjtés alapján kiválasztott civil szervezete szolgált. A vizsgálatban a következỏ szervezetek vettek részt: az Ormánság Fejlesztô Társulás Egyesület, az Együtt a Kémes Körzet Gyermekeiért Alapítvány, a Szociális Háló Egyesület, a Drávazug Társulás Egyesület és az „Együtt Csányoszróért” Egyesület. Ezek közül a Szociális Háló Egyesület abban a tekintetben eltér a többi szervezettől, hogy pécsi tagintézménnyel is rendelkezik, így az interjú elkészítése során lehetõségem nyilt mind a pécsi, mind a sellyei intézményt is személyesen felkeresni. Az öt felkeresett civil szervezet kiválasztásában alapvetô követelményként jelent meg, hogy a lefedett területet és a lakosság számát tekintve a nagyobb, akár az egész Ormánság életében befolyással bíró szervezetek éppúgy képviseltessék magukat, mint a csak egy kisebb település fejlődésében szerepet játszó civil kezdeményezések. Ezzel lehetőség nyilt a kistérség civil életének több szegmensből való megismerésére, vizsgálatára.

$\mathrm{Az}$ Ormánsági civil szervezetek intézményei föleg a tájegység fôvárosaként aposztrofált Sellyén találhatóak, de emellett több szervezet mủködik kisebb falvakban és községekben is. Számos közülük a megyeszékhelyen, Pécsett is rendelkezik irodával, társintézménnyel. Ennek fontos szerepe van az anyagi források elốteremtésében és a megfelelô, képzett munkaerő felvételében, a szervezet promótálásában. A $\mathrm{KSH}$ adatfelvételei során létrehozott TSAR- 
adatbázis szolgált a következổ két táblázat alapjául. A civil szervezetek jelenléte a Sellyei kistérségben az 1999-es évtől egy kisebb visszaesést követôen lassan, de folyamatosan nổtt. Ennek egyik fổ oka a pályázati rendszer és az eléthetổ források számának növekedése volt (1. és 2 . táblázat).

A 2004-es Európai Uniós csatlakozást megelőzôen lehetôség nyilt azz úgynevezett „elốcsatlakozási alapok”lehívására (PHARE, ISPA, SAPARD). 2006-ig kellett elkészítenie a kormánynak az országos fejlesztési stratégiáját (Nemzeti Fejlesztési Terv II.), aminek alapján az ország 2007-2013-ban is részesülhet az európai kohéziós politika eszközei, jelentette támogatásokból. Ezek a fortások a Regionális Operatív Program (ROP) keretein belül fejtik ki hatásukat.

1. táblázat. Civil szervezetele a Sellyei Kistérségben 1999-2008

\begin{tabular}{|l|l|l|l|l|l|l|l|l|l|}
\hline 1999 & 2000 & 2001 & 2002 & 2003 & 2004 & 2005 & 2006 & 2007 & 2008 \\
\hline 101 & 101 & 102 & 99 & 96 & 106 & 110 & 109 & 113 & 115 \\
\hline
\end{tabular}

Forrás: KSH-TSTAR 2009

A kistérség egyike az ország gazdaságilag legelmaradottabb térségeinek. A két legsúlyosabb probléma a magas munkanélküliség és a fokozott migráció. A munkavállalás lehetôségének hiánya a lakosság körében gyakran 2. és 3. generációs szinten is továbböröklödik, ezzel is erôsítve a térség leszakadását (1. ábra). A migrációs tendenciákat vizsgálva, azt a megállapítást tehetjük, hogy a hátrányos helyzetû̉ települések elvándorló lakossága a térség két központjában Selylyén és Vajszlón, illetve a megyeszékhelyen koncentrálódik (2. ábra). A nagyobb települések népességelszivó hatást fejtenek ki a kisebb falvak lakosságának rovására, csökkentve a helyi civil szervezetek további esélyeit. A migráció oka a magas munkanélküliség, a kilátástalanság, a szolgáltatások jobb elérhetôsége, valamint a romló egészségügyi ellátórendszer, illetve annak visszavonulása a falvakból. Elsősorban azok költöznek el a területrổ, akik a munkaerôpiacon kedvezốbb pozícióban vannak (fiatalok, képzettek, társadalmi és anyagi tőkével rendelkezők), míg a leghátrányosabb helyzetủek (képzetlenek, romák, idősek) inkább helyben maradnak.
2. táblázat. A civil szervezetele számának változása településenkénti bontásban 1999-2008

\begin{tabular}{|c|c|c|c|c|c|c|c|c|c|c|}
\hline Település & 1999 & 2000 & 2001 & 2002 & 2003 & 2004 & 2005 & 2006 & 2007 & 2008 \\
\hline Sellye & 23 & 22 & 21 & 21 & 24 & 25 & 25 & 25 & 25 & 26 \\
\hline \multicolumn{11}{|l|}{ Adorjás } \\
\hline Baranyahidvég & 1 & 1 & 1 & 1 & 1 & 1 & 1 & 1 & 1 & 1 \\
\hline Besence & 1 & 1 & 1 & 1 & 1 & 1 & 1 & 1 & 1 & \\
\hline Bogádmindszent & 5 & 5 & 5 & 4 & 3 & 3 & 3 & 2 & 2 & 1 \\
\hline Csányoszró & 6 & 6 & 6 & 6 & 7 & 7 & 7 & 7 & 7 & 8 \\
\hline Drávafok & 5 & 6 & 9 & 8 & 7 & 9 & 9 & 9 & 9 & 8 \\
\hline \multicolumn{11}{|l|}{ Drávaiványi } \\
\hline Drávakeresztúr & & & & 1 & & & & & & \\
\hline Drávasztára & 4 & 4 & 4 & 4 & 4 & 4 & 4 & 4 & 5 & 5 \\
\hline Felsószentmárton & 7 & 6 & 6 & 6 & 6 & 7 & 9 & 9 & 9 & 9 \\
\hline Gilvánfa & 5 & 4 & 4 & 4 & 1 & 1 & 1 & 1 & 1 & 1 \\
\hline Hegyszentmárton & 3 & 3 & 3 & 3 & 3 & 4 & 4 & 4 & 5 & 7 \\
\hline Hirics & 1 & 1 & 1 & 1 & 1 & 1 & 1 & 1 & 1 & 1 \\
\hline \multicolumn{11}{|l|}{ Kákics } \\
\hline \multicolumn{11}{|l|}{ Kemse } \\
\hline Kisasszonyfa & 2 & 2 & 2 & 2 & 2 & 2 & 2 & 3 & 4 & 4 \\
\hline Kisszentmárton & 2 & 2 & 2 & 2 & 1 & 1 & 1 & 1 & 1 & 1 \\
\hline \multicolumn{11}{|l|}{ Kórós } \\
\hline Lúzsok & 1 & 1 & & & & & & & & \\
\hline Magyarmecske & 3 & 3 & 3 & 3 & 3 & 3 & 3 & 3 & 3 & 3 \\
\hline Magyartelek & 1 & 1 & 1 & 1 & 1 & 1 & 1 & 1 & 1 & 1 \\
\hline \multicolumn{11}{|l|}{ Markóc } \\
\hline Marócsa & & 1 & 1 & 1 & 1 & 1 & 1 & 1 & 1 & 1 \\
\hline Nagycsány & 2 & 2 & 2 & 2 & 2 & 2 & 2 & 2 & 1 & 1 \\
\hline \multicolumn{11}{|l|}{ Okorág } \\
\hline Ózdfalu & & & 1 & 1 & 1 & 1 & 1 & 1 & 1 & 1 \\
\hline \multicolumn{11}{|l|}{ Páprád } \\
\hline Piskó & 2 & 2 & 2 & 2 & 2 & 2 & 2 & 2 & 2 & 2 \\
\hline Sámod & 2 & 3 & 3 & 2 & 2 & 2 & 2 & 2 & 2 & 2 \\
\hline \multicolumn{11}{|l|}{ Sósvertike } \\
\hline Vajszló & 17 & 17 & 16 & 16 & 16 & 20 & 21 & 20 & 22 & 22 \\
\hline Vejti & 1 & 1 & 1 & & & & & & & \\
\hline
\end{tabular}

Forrás: KSH-TSTAR 2009 


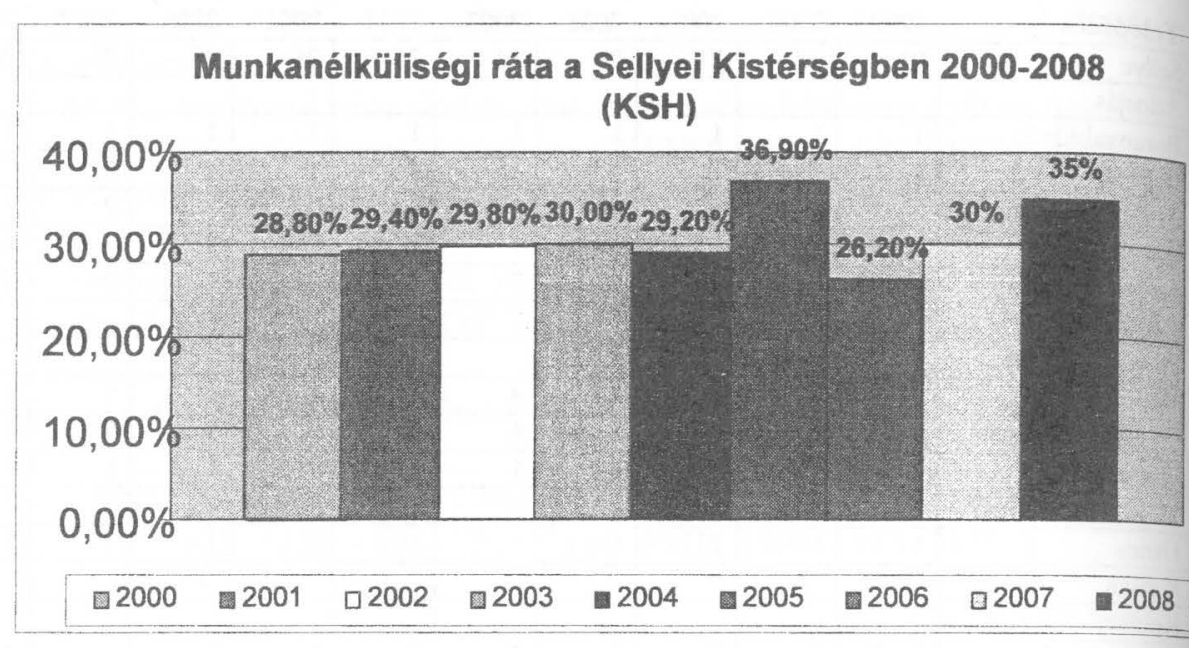

2. ábra

A Sellyei Kistérség népességváltozása 2001-2008 - 920 fó (KSH)

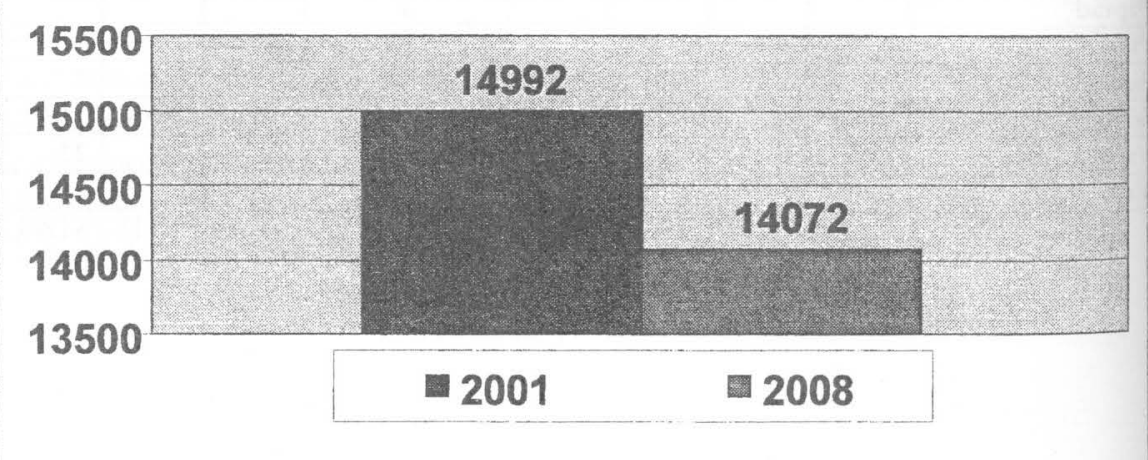

Forrás: KSH-TSTAR 2009
A Szociológia Tanszék több hallgatójával közösen végzett munka eredményeképpen, a megkeresett szervezetek valamennyi vezetôjével és néhány munkatársával is sikerült több interjút elkészíteni. Az interjúk és az adatgyújtés eredményei alapján a civil szektorra általában jellemzô minden ismérv kirajzolódni látszik - legyen az negatív vagy pozitív. A következőkben, a teljesség igénye nélkül csak pár mondatban szólnék a szervezetek tevékenységi körérổ, majd részletesen kitérek a kapcsolatrendszerükre és a szervezeteket sújtó nehézségekre.

A mintavétel egyik alanya az Együtt a Kémes Körzet Gyermekeiért Alapítvány volt. Az alapitvány célja, hogy fejlessze a közösségi életet és kultúrát, hogy a szabadidős tevékenység által élhetőbb környezetet hozzanak létre. A szervezet tevékenységétổl több dolgot is vámak, a tanuláshoz szükséges motiváció elősegítését, munkaerỏpiaci esélyek javulását, a cigány származású fiatalok hatékonyabb integrálódását, a helyi identitás növekedését, illetve az aktívabb közösségi életet. Az alapítvány tátsadalmi támogatottsága magas, azonban anyagi lehetôségeik erôsen korlátozottak.

$\mathrm{Az}$ „Együtt Csányoszróért” Egyesületnél az elmúlt tiz évben több mint 30 év lemaradását hozták be, mindehhez szükséges volt a település lakóinak szemléletváltozása is. $\mathrm{Az}$ önkormányzat a területfejlesztési alaptól közösségteremto̊ céllal nyert támogatást egy sajátos programhoz, a faluközpont a község lakói által öntevékenyen elvégzendố fásításához. Az egyesület jelentôs szerepet vállal a település lakosságának közösséggé kovácsolásában, tevékenységével elổmozdítja az esztétikus falukép kialakitását. A jövőben a kis léptékủ fejlesztéseket szeretnék folytatni. Azonban az egyesület eléthetỏ források hiányában nem lesz 'épes a jelenlegi helyzetén lényegesen változtatni. Állami segítségre lenne szükség, ám a jobbító szándéknak eddig nem sok jelét tapasztalták

A Drávazug Társulás Egyesület Drávafokon mủködik. A szervezet legfőbb profilja a hatátokon átívelő kapcsolatok kialakitása, azok fenntartása, fổleg Németországgal és Ausztriával. A vizsgált szervezetek közül a Drávazug Társulás Egyesület van az anyagi és a társadalmi támogatottságát tekintve a legrosszabb helyzetben. Míg a többi szervezet képes állandóan megújulni, progtamokat szervezni, addig ez Drávafokon hiányzik. A lakosság aktivitásának hiánya mellett a rendelkezésre álló források szükössége is gátat szab elképzeléseiknek.

Az Ormánság Fejlesztỏ Társulás Egyesület (a továbbiakban OFT) az általa lefedett 48 településen végzi munkáját (a terület közel $323 \mathrm{~km} 2$-t ölel fel, ahol nagyjából 21. 000 ember él). Ezzel az Ormánság legnagyobb civil szervezete. Az egyesület jelenleg kapacitástól függő̉en fổleg tanulmányok készitésével, pályázatok irásával illetve településfejlesztési koncepciók kidolgozásával foglalkozik. Olyan kisebb források megszerzése a cél, amelyekről a helyi szereplők vagy nem tudnak, vagy nem éri meg profi pályázatíró céget felbérelni. Nyitnak Horvátor- 
szág felé is, közös progtamokat szervezve próbálják a két ország közösségeit közelebb hozni egymáshoz.

A Szociális Háló Egyesület a kistérség szocialis és egészségügyi szférájában lát el fontos feladatokat. A fekvőbeteg- és a szakápolói munka mellett a HOSPICE-szolgálatot tekintik egyik legfontosabb feladatuknak. Az Ormánságban azért van szükség az ellátórendszer kiterjesztésére, mert ez a terület az országos statisztikák szerint a legrosszabb egészségügyi mutatókkal rendelkezik. Falunapokkal próbálják felhívni az emberek figyelmét az egészségesebb élet elônyeire, illetve a Vöröskereszt támogatásával adományokat osztanak (főleg tartós élelmiszert, ruhát és bútort).

\section{Társadalmi tőke - Kapcsolatrendszer}

A civil társadalom egyik sarokkövének számít az együttmûködés, a kooperativ munka. A kiterjedt kapcsolatrendszer (társadalmi tôke) mindenképpen szükséges egy civil szervezet munkáját illetôen. Egy szervezet, legyen az egy kistelepülésen vagy a fỗvárosban, elônyỏs lehetốségekhez juthat, ha széles körben ismert vagy elismert munkát végez. Az ormánsági civilek is jelentốs energiát forditanak a jó kapcsolatok kialakitására, mind a civil, mind a kormányzati szektorban (önkormányzatok, állami és rendvédelmi szervezetek). Az Együtt a Kémes Körzet Gyermekeiért Alapítványt és a Drávazug Társulás Egyesületet erős szálak füzik nérnet és osztrák civil szervezetekhez. Az OFT, mint a vizsgált szervezetek közül a legjelentôsebb, szoros kapcsolatot ápol a térség civil szervezeteivel, közel tizenkét civil szervezettel állnak kapcsolatban. Számukra gyakran írnak pályázatokat is. Ide tartozik például a Martince Kulturális Egyesület, a Vajszló és Vidéke Kulturális Egyesület, a Vajszlói Nyugdíjasok Klubja, a Vajszlói Polgárőr Egyesület, a Kisszentmártonért Egyesület. Az utóbbi években megjelentek a határokon átívelố projektek is. Öt horvát civil szervezettel vették fel a kapcsolatot, a horvátországi Dráva Mente megyéből. Ennek eredményeképpen alártak egy kulturális kerekasztal felállitásáról szóló megállapodást, ami arra hivatott, hogy a két nemzet kulturális kapcsolatait közösen ápolják, közös programokkal, egymást segítve. Az „Együtt Csányoszróért” Egyesület jó kapcsolatot ápol a helyi önkormányzattal, amely lehetôségeihez mérten mindenben támogatja őket, nemcsak anyagi éttelemben, hanem a szervezésben illetve az ügyintézésben is. A településen található vállalkozókkal is igyekszik az egyesület minél jobb kapcsolatot fenntartani, ami sikeresnek mondható. Megjeleníti és képviseli a civil szektort, megismerteti tevékenységét a lakossággal és a települési önkormányzattal. Segiti a különbözổ közösségek közötti párbeszédek létrejöttét, az információáramlást, tájékoztatást.

A szervezetek egymáshoz való viszonya nem minden esetben nevezhetổ jónak. Országos viszonylatban elmondható, hogy gyaktan bizalmatlanok egymással, a szolidaritás csekély. Budapest-centrikusság érvényesül az információ- áramlásban, a pályázati lehetổségek tekintetében. Az emyőszervezetek gyakran nem ismerik a helyi problémákat. A tudományos kutatások eredményei nem jutnak vissza a szervezetekhez, nem épülnek be a gyakorlati alkalmaźśsb. Hiányzik a szervezettség, kevesen hisznek a közös érdekképviseletben, vagy tesznek érte. Elégtelen az információ a központi fortásokról, illetve az államkasszába befolyó összegekröl.

A mintavétel során kiderült, hogy a szervezetek a pályázati pénzek lehívása és a közösségi élet szervezése mellett a kapcsolatrendszer állandó építését tekintik a legfontosabb feladatuknak. Tisztában vannak azzal, hogy egy elszigetelt civil kezdeményezés, legyen bát innovatív, nem képes hosszú távon fennmaradni. A jövőben folytatniuk kell a kapcsolatépitést az állami és a civil szektorban egyaránt. A kiterjedt kapcsolatrendszer lehetőséget biztosíthat a fejlôdésre és a jövổbeli projektek megvalósitására, az anyagi források elôteremtésére.

\section{A civil szektor nehézségei}

Milyen természetũ problémákkal küzd a civil szektor? Számos alapítvány, egyesület múködik az országban, akik jól élve a lehetôségekkel, a kapcsolati és anyagi tőkére alapozva sikeresen végzik munkájukat, ennek ellenére jelentôs nehézségek sújtiák a szektor résztvevổit. Ennek elsôdleges okát az anyagi források hiányosságában kell keresnünk. Az Európai Unióhoz történt csatlakozás után - valamint a hazai tendszer folyamatos bővülése mellett - jelentôs pályázati pénzek (HEFOP, TAMOP, NCA, stb.) lehívásáta adódott lehetôség. Legyen szó hazai vagy külföldi forrásról, a rendszer rugalmatlansága, a túlzott elvárások, a kifizetések gyakori csúszása, valamint a határidők mégis gyakran gátat szabnak az elképzeléseknek, és folyamatos bizonytalanságban tartiák a szervezetek munkatársait és a közösséget egyaránt. A szervezetek müködése gyakran nem folyamatos, az egyik program végétôl a következõ elnyeréséig tart. A kisebbek kiszorulnak a szükülỗ pályázati lehetôségekből, más forrásokat, pénzszerzési lehetôségeket nem ismernek. Gyakran a közüzemi költségeket és béreket is pályázati pénzből vannak finanszírozva, így a napi munka, az alkalmazottak bérezése is komoly problémát jelenthet. A helyi önkormányzatok és az állam csak minimális anyagi támogatást képes nyújtani az egyesületeknek az állandó lobbitevékenység ellenére. Ide kapcsolódó probléma, hogy a pályázatíráshoz szükséges szakemberek hiánya szintén hátráltató tényezỏ a lehetséges támogatások, bevételek megszerzésében. A pályázati pénzek mellett egy másik lehetséges bevételi forrás az SZJA 1\%-a, illetve különböző adományok (helyi vállalkozók, elszármazott egykori lakosok, társszervezetek). Azonban túl sok a pályázó, kevés a forrás, kevés a jelentôs összeget adományozók száma, szük a támogatói kör, kevés a pályázati lehetôség. Az adományozók gyakran nem ismerik még helyi szinten sem a szervezeteket. A vizsgált szervezetek álláspontia az, hogy az állam több pénzt szánhatna a civil szervezetek müködésére, fôleg azoknak a 
működésére, amelyek a lakosság, a környezet fejlődését segítik. Ez azt jelenti, hogy azzal kellene támogatni a szervezeteket, hogy az ott dolgozók ne ingyen dolgozzanak, hiszen nem várható el hogy mindenki csak önkéntesen dolgozzon. Az alkalmazásban álló szakemberek túlterheltek, kevesen végeznek sok munkát. A továbbképzési lehetôségek csak egy szük kör számára érhetổek el, mert túl drágák vagy kevés az információ róluk. A szervezetek nem ismemek új forrásteremtési módokat. $\mathrm{Az}$ infrastruktúra terén is jelentôs hátrányokkal küzdenek a civil szervezetek, gyenge a meglévô infrastrukturális háttér. A kisebb szervezetek csak minimális lehetôségekkel rendelkeznek. Az eltérõ infrastrukturális bázis miatt nem egyenlő az információhoz jutás esélye sem. Az emyôszervezetek nem alakítottak ki olyan hálózatokat, mechanizmusokat, amelyek biztosíthatnák a zavartalan müködést.

A civil szervezetek munkáját egy másik szintén súlyos probléma is nehezít, a motiváció hiánya. Az interjúk kapcsán gyakran felmerült, hogy a lakosságot nehéz bevonni a közösséget érintő aktuális programokba. Számos esetben elōfordult, hogy csak bizonyos kompenzáció (pl. tombola, ingyen ebéd stb.) fejében lehetett az embereket mozgósítani. Az Együtt a Kémes Körzet Gyermekeiért Alapítvány elnöke elmondta, hogy a résztvevôk száma a programokon általában a motivációtól függ. Az elnök szerint sok múlik a motiváción, illetve azon, hogy hogyan vannak megszólítva az embereket. A lakosság, illetve a kiemelt célcsoport többnyire aktívnak mondható, bevonható. Ha a szervezök úgy találják, hogy kevesebb számban jönnek el a programokra, akkor kitalálnak valamilyen motivációs eszközt.

A politika szintjén gyakori probléma, hogy a civil szervezetekben az önkormányzatok gyakran riválist és nem partnert látnak, lehetetlen igényeket támasztanak, nem ismerik fel a helyi problémákat. Az önkormányzat nem, vagy csak ritkán kérdezi meg a szervezetek véleményét és vonja be őket a döntéshozatalba vagy a döntés-előkészítésbe. $\mathrm{Az}$ egyeztetési fórumok sokszor csak a látszat szintjén mủködnek. Több esetben a forprofit szervezetekkel is versenyezni kell a forrásokért. Szükségesnek tartom megemlíteni, hogy bát a civilek gyakran súlyos nehézségekkel küzdenek, mégis képesek alkalmazkodni a folyamatosan változó igényekhez. Egyre több különböző szervezetet hoznak létre, bizonyítva ezzel a szektor szükségességét.

\section{Záró gondolatok}

$\mathrm{A} z$ említett szervezetek jelentős részt vállalnak a Sellyei Kistérség társadalmának életében. Az új kihívások folyamatos cselekvésbeli stratégiák, döntések kidolgozását követelik meg a szektor résztvevôitőll és a politikai élet szerepvállalóitól. $\mathrm{A} z$ utóbbi évek jelentôs erôfeszítései ellenére még nem állt meg a leszakadás folyamata a Sellyei Kistérségben. A legsürgôsebb cél ezen leszakadás mérséklése, majd ezt követỏen a kitörési pontok mentén a kistérség fejlődési pályára történô állitása. Szinte biztos, hogy az égetôen sürgổs fejlesztések célirányos kormányzati segitség nélkül, önerôboỏl nem valósithatók meg. A civilek munkájával kapcsolatban kijelenthetjük, hogy az innovatívan gondolkodó emberekbổ egyik településen sincs hiány. A felzárkóztatás, a halmozottan hátrányos helyzetben élô, sok esetben mélyszegény lakosság integrálása, illetve a helyi társadalom közösséggé formálása megvalósítható. Azonban a civil szervezetek munkájába még erôteljesebben be kell vonni a lakosságot, hiszen megfelelổ társadalmi támogatottság nélkül az elképzelések és projektek sem valósíthatók meg. Konszenzust kell kiépíteni a szereplőknnek a fejlesztési célok és prioritások elfogadásában; ütőképes területfejlesztési, pénzügyi és műszaki szakemberekből álló gárdát kell felállitani, hiszen nem csak a pályázatok elö- és elkészítése igényel komoly anyagi és szellemi erôforrásokat, hanem a megvalósitás és az üzemeltetés is.

A fenti gondolatok és tapasztalatok alapján igazolódni látszik a bevezetôben megfogalmazott hipotézis. A civil szervezetek sok esetben valóban képesek integráló hatást kiváltani egy adott mikto vagy makro közösségen belül. Ehhez azonban szükséges a „hátország” valós támogatása, az anyagi és infrastrukturális források megléte. 